\title{
Sprawozdanie z Ogólnopolskiej Interdyscyplinarnej Konferencji Naukowej Wyzwania wspótczesnego prawa wyborczego. Toruń, 15 marca 2013 r.
}

Słowa klucze: Wyzwania współczesnego prawa wyborczego, Studenckie Koło Naukowe „Elektor", Rzecznik Praw Obywatelskich

15 marca 2013 r. w gmachu Collegium Iuridicum Novum w Toruniu miały miejsce obrady Ogólnopolskiej Interdyscyplinarnej Konferencji Naukowej „Wyzwania współczesnego prawa wyborczego". Organizatorem tego przedsięwzięcia byli entuzjaści prawa wyborczego działający w Studenckim Kole Naukowym Prawa Wyborczego „Elektor” UMK. W związku ze szczególną tematyką konferencji patronat honorowy nad wydarzeniem objęli: Minister Nauki i Szkolnictwa Wyższego, Rzecznik Praw Obywatelskich, Marszałek Województwa Kujawsko-Pomorskiego, Prezydent Miasta Torunia, Prorektor ds. Studenckich i Polityki Kadrowej UMK oraz Dziekan Wydziału Prawa i Administracji UMK. Konferencja odbyła się pod patronatem medialnym Wydawnictwa C. H. Beck, TV Toruń oraz serwisów prawniczych: LegalNews24.pl i sPrawnik.pl.

Wydarzenie rozpoczęło oficjalne powitanie wszystkich zgromadzonych przez Prezesa SKNPW „Elektor” Agatę Pyrzyńską. Wśród wyjątkowych gości konferencji wymienić należy: sędziego Stefana Jana Jaworskiego - Przewodniczącego Państwowej Komisji Wyborczej, ministra Kazimierza Wojciecha Czaplickiego - szefa Krajowego Biura Wyborczego, Mirosława Wróblewskiego - Dyrektora Zespołu Prawa Konstytucyjnego i Międzynarodowego w Biurze Rzecznika Praw Obywatelskich, Alexandra Shlyka - Election Adviser w OSCE/ODIHR, prof. Andrzeja Sokalę - kierownika Centrum Studiów Wyborczych UMK oraz dra Jarosława 
Zbieranka - eksperta Centrum Studiów Wyborczych UMK. Na konferencję przybyli także studenci oraz doktoranci reprezentujący ośrodki akademickie niemalże z całej Polski, w tym z Krakowa, Warszawy, Wrocławia, Gdańska, Poznania, Białegostoku, Lublina, Łodzi, Olsztyna oraz Torunia. Po oficjalnym powitaniu wszystkich gości, głos zabrali przedstawiciele patronów honorowych konferencji.

Po części otwierającej konferencję rozpoczął się panel ekspercki moderowany przez mgr Annę Frydrych z Centrum Studiów Wyborczych UMK. Prowadząca na wstępie podkreśliła, iż toruńska konferencja to wydarzenie wyjątkowe, gdyż jest to pierwsze tego typu przedsięwzięcie w pełni poświęcone prawu wyborczemu, którego inicjatorem byli wyłącznie studenci. Następnie, po przedstawieniu wszystkich prelegentów panelu, jako pierwszy o głos poproszony został Przewodniczący Państwowej Komisji Wyborczej, S. J. Jaworski. Prelegent wśród zasadniczych wyzwań, przed którymi stoi dziś prawo wyborcze wymienił w pierwszej kolejności konieczność aktywizacji innych ośrodków akademickich w zakresie działań mających na celu propagowanie wiedzy o prawie wyborczym na wzór ośrodka toruńskiego. Jako drugie z wyzwań Sędzia Jaworski wskazał konieczność rozwiania wątpliwości dotyczących nowych technik głosowania (głosowania przez pełnomocnika, głosowania korespondencyjnego, elektronicznych technik przekazywania danych w przypadku głosowania internetowego). Prelegent podkreślił przy tym, że nie ma najmniejszych wątpliwości, iż wybory począwszy od roku 1990 są przeprowadzane przez polskie organy wyborcze sprawnie i uczciwie. Trzecim z wymienionych przez Przewodniczącego Jaworskiego wyzwań był postulat skierowany do ustawodawcy konstytucyjnego, wskazujący na potrzebę odstąpienia od zamkniętego katalogu źródeł prawa, który obecnie pozbawia PKW możliwości optymalnego sterowania procesem wyborczym. Drugi z ekspertów, Minister Czaplicki w swoim wystąpieniu zwrócił uwagę na to, iż de facto katalog wyzwań współczesnego prawa wyborczego, przed którymi stoi tak polski ustawodawca, jak i organy realizujące prawo wyborcze, jest bardzo szeroki. Minister w trakcie wypowiedzi skupił się na zagadnieniu równości szans wszystkich podmiotów uczestniczących w wyborach, w tym kandydatów, partii politycznych, jak również samych wyborców. Zwrócił także uwagę, iż obecnie wielkim wyzwaniem dla prawa wyborczego staje się postępujący rozwój środków komunikowania na odległość, a co za tym idzie - możliwość efektywnego wykorzystania takich narzędzi komunikacji jak Internet, w tym także portali społecznościowych, w prowadzeniu kampanii wyborczej przy jednoczesnym istnieniu pewnych ustawowych ograniczeń jak chociażby cisza wyborcza. Trzeci z ekspertów, Mirosław Wróblewski z Biura Rzecznika Praw Obywatelskich, zwrócił uwagę przede wszystkim na te wyzwania prawa wyborczego, które dotyczą osób niepełnosprawnych. Prelegent przypomniał, iż 
ustawodawca w Kodeksie wyborczym dokonał w pewnym sensie „rewolucji” poprzez wprowadzenie obowiązku dostosowania co najmniej 1/3 lokali wyborczych w każdej gminie do potrzeb wyborców niepełnosprawnych (docelowo zaś wszystkich lokali wyborczych). Zwrócił przy tym uwagę na fakt, iż pomimo ratyfikacji przez Polskę Konwencji ONZ o prawach osób niepełnosprawnych w przepisach prawa budowlanego nie znalazł się dotychczas przepis wskazujący na jakąkolwiek perspektywę czasową dla dostosowania budynków użyteczności publicznej, czy w ogóle budynków niebędących nowo wybudowanymi lub remontowanymi, dla potrzeb wyborców niepełnosprawnych. Jak wskazał M. Wróblewski, prawo wyborcze ma zatem szansę zostać swego rodzaju „awangardą” w tym obszarze, a w dalszej perspektywie „promieniować” na inne obszary prawa. Prelegent w swojej wypowiedzi odniósł się również do problematyki alternatywnych sposobów głosowania, wskazując na potrzebę wprowadzenia głosowania elektronicznego w przyszłości. Kończąc swoje rozważania referent podkreślił także konieczność podjęcia przez ustawodawcę działań mających na celu zapewnienie środków służących edukacji wyborczej, w tym w zakresie nowych metod głosowania. Alexander Shlyk z Biura Instytucji Demokratycznych i Praw Człowieka Organizacji Bezpieczeństwa i Współpracy w Europie rozpoczął swoje wystąpienie od krótkiego wyjaśnienia kompetencji ODIHR/OSCE. W dalszej kolejności prelegent scharakteryzował zobowiązania OBWE wynikające z Dokumentu kopenhaskiego z 1990 roku ${ }^{1}$. Podkreślił nadto, że analiza prawa wyborczego nie powinna ograniczać się wyłącznie do przepisów, ważne jest także badanie ich zastosowania w praktyce wyborczej, która w związku z postępem technicznym, ulega istotnym zmianom. Doktor Jarosław Zbieranek w swoim wystąpieniu zwrócił uwagę na fakt, iż przyjęcie nowych rozwiązań w Kodeksie wyborczym to ważny krok do przodu w kontekście zapewnienia gwarancji zasady powszechności wyborów. Zauważył także, iż pierwsze doświadczenia przy zastosowaniu regulacji Kodeksu pozwalają na dokonanie pozytywnej oceny nowych rozwiązań, choć rzecz jasna, nie jest to regulacja idealna. Prelegent podkreślił, że dużym wyzwaniem pozostaje kwestia informowania wyborców o nowych instytucjach i procedurach zawartych w ustawie wyborczej. Doktor Zbieranek zauważył nadto, iż niebagatelnym wyzwaniem dla prawa wyborczego może stać się perspektywa likwidacji obowiązku meldunkowego w drodze zmiany ustawy o ewidencji ludności. Prelegent zwrócił uwagę na to, że zmiana ta może generować poważne problemy dla wyborców wynikające

1 Wymieniony dokument to: Document of the Copenhagen Meeting of the Conference on the Human Dimension of the OSCE, przyjęty 29 czerwca 1990 roku na Konferencji KBWE w Kopenhadze. 
z likwidacji rejestru mieszkańców, na którym oparty jest rejestr wyborców, co może znacznie skomplikować mechanizmy wyborcze związane z koniecznością rejestracji wyborców. Profesor Andrzej Sokala dokonał podsumowania wystąpień wszystkich ekspertów. Prelegent zaakcentował, iż system wyborczy, który udało się zbudować w przeciągu ostatnich dwudziestu pięciu lat, w pełni demokratyczny i sprawnie funkcjonujący, to istotne osiągnięcie i powód do dumy. Profesor zgodził się z przedmówcami, iż kwestia edukowania w zakresie wiedzy wyborczej to ważne wyzwanie dla prawa wyborczego i zaapelował, aby w większym stopniu w misję tę włączone zostały także władze samorządowe. Wśród istotnych wyzwań prof. Sokala wymienił nadto, zgłaszaną już kilkukrotnie, potrzebę instytucjonalnego wzmocnienia Państwowej Komisji Wyborczej poprzez jej konstytucjonalizację. Po zakończeniu wypowiedzi ekspertów nastąpiła interesująca dyskusja pomiędzy zaproszonymi specjalistami z zakresu prawa wyborczego a pozostałymi uczestnikami wydarzenia.

Dalsze rozważania uczestników konferencji odbywały się w 8 panelach tematycznych, każdy z nich pod kierunkiem jednego z gości występujących w panelu eksperckim. Stanowiło to ważne wyróżnienie dla prelegentów - studentów i doktorantów, mogących przedstawić swoje spojrzenie na zaproponowany przez organizatorów temat przewodni pod okiem najwybitniejszych znawców tematu. Dwa pierwsze odbywające się równolegle panele studencko-doktoranckie zatytułowane zostały: Gtosowanie - stan obecny i postulaty oraz Bezpieczeństwo wyborów - sankcje i gwarancje. Pierwszemu z wymienionych przewodniczył sędzia Jaworski. Tematy poruszone przez referentów dotyczyły zarówno instytucji przewidzianych przez Kodeks wyborczy, w tym głosowania korespondencyjnego oraz głosowania przez pełnomocnika, jak również instytucji prawa wyborczego obowiązujących w obcych systemach prawnych, nieznanych polskiej ustawie wyborczej, jak głosowanie elektroniczne czy dość kontrowersyjna konstrukcja none of the above. Prelegenci przedstawili istotę poszczególnych instytucji, wskazując na wady i zalety poszczególnych rozwiązań, jak również formułowali własne postulaty de lege ferenda. W drugim z paneli, moderowanym przez ministra Czaplickiego, referenci skupili się na przedstawieniu takich zagadnień jak zakres penalizacji niektórych czynów zabronionych na gruncie polskiego Kodeksu wyborczego (na tle prawonoporównawczym) oraz omówili wybrane problemy przestępczości wyborczej w Polsce. Nadto referenci zwrócili uwagę słuchaczy na instytucje gwarantujące bezpieczeństwo i w pełni demokratyczny wymiar aktu wyborczego - w tym instytucje mężów zaufania w polskim prawie wyborczym oraz międzynarodowego obserwatora wyborów.

Kolejny blok panelowy koncentrował się na zagadnieniach przewodnich: Prawo wyborcze $w$ wybranych państwach świata oraz Kampania wyborcza w Pol- 
sce. W pierwszym z paneli, prowadzonym przez A. Shyka, prelegenci poruszyli problematykę systemu wyborczego Węgier, Republiki Malty (z uwzględnieniem systemu proporcjonalnego single transferable vote), a także zasygnalizowali problemy związane z wyborem prezydenta USA oraz regułami finansowania kampanii wyborczej na Ukrainie w 2012 r. Referenci występujący w równoległym panelu moderowanym przez dra J. Zbieranka zapoznali słuchaczy z wyzwaniami prawa wyborczego dotyczącymi szeroko pojętej kampanii wyborczej. Prelegenci odnieśli się w swoich wystąpieniach do zjawiska określanego mianem ghostwriting, a także sposobów wykorzystania wizerunku polityków w trakcie kampanii wyborczej. Omówiony został także problem ochrony dóbr osobistych polityków ze szczególnym uwzględnieniem tzw. trybu wyborczego z art. 111 k. w. Nadto zwrócono uwagę na rolę kampanii wyborczej w podwyższaniu jakości polskiego życia publicznego a także na problem granic kampanii informacyjnych w kontekście instytucji agitacji wyborczej.

Trzeci blok panelowy dotyczył zagadnień: Równosć w prawie wyborczym oraz Prawo wyborcze wobec potrzeb wspótczesnych społeczeństw. W pierwszym z wymienionych prelegenci obradowali pod kierunkiem M. Wróblewskiego. W panelu tym podjęto tematy dotyczące partycypacji kobiet w polskiej polityce, udziału mediów w kampanii wyborczej, a także wpływu gerrymanderingu na wynik wyborów. Nie zabrakło także politologicznego ujęcia tematu przewodniego panelu w postaci charakterystyki zasady konkurencyjności wyborów. W panelu równoległym dyskusji przewodził dr M. Sobczyk, zaś prelegenci skupili się m.in. na wskazaniu postulatów nowego kształtu demokracji wynikających z postępu technicznego, niebezpieczeństwach związanych z likwidacją w polskim prawie obowiązku meldunkowego w kontekście rejestru wyborców czy potrzebie uregulowania w ustawie wyborczej instytucji sondażu przedwyborczego. Referenci rozważali nadto zasadność utrzymania w polskim prawie wyborczym instytucji ciszy wyborczej. Debatowano także nad pomysłem wprowadzenia cenzusów wyborczych do współczesnego prawa wyborczego.

Dwa ostatnie panele konferencyjne: Jednomandatowe okregi wyborcze oraz Wyborczy kalejdoskop mimo późnej pory również zgromadziły wielu słuchaczy. Zadania poprowadzenia dyskusji o jednomandatowych okręgach wyborczych (JOW) podjął się mgr M. Piwnicki. W trakcie panelu analizie poddano przyczyny i zasadność wprowadzenia JOW w wyborach do Senatu RP, omówiono wybrane problemy prawne dotyczące JOW w wyborach samorządowych a także przedstawiono projekt zmian w Kodeksie wyborczym przygotowany przez Fundację im. J. Madisona Centrum Rozwoju Demokracji zawierający propozycję wprowadzenia JOW w wyborach do Sejmu RP. Panel zatytułowany Wyborczy kalejdoskop poprowa- 
dził mgr R. Zych. W jego trakcie omówione zostało prawo wyborcze w polskich konstytucjach, zagadnienie wyborów władz w polskich związkach sportowych, a także problem motywowania partycypacji wyborczej w Polsce.

Konferencja „Wyzwania współczesnego prawa wyborczego” spotkała się $\mathrm{z}$ bardzo dużym zainteresowaniem. Jest to zatem ważny sygnał dla organizatorów, a także innych ośrodków akademickich, iż prawo wyborcze to nie tylko wąska dziedzina, będąca częścią prawa konstytucyjnego, ale stwarzająca szerokie pole do analizy i interpretacji gałąź prawa, szczególnie istotna z punktu widzenia każdego wyborcy. Zwieńczenie i rozwinięcie obrad konferencji stanowić będzie planowana publikacja pokonferencyjna. 